Short communication

\title{
New distributional record of Zingiber roseum (Roxb.) Roscoe from Satpuda hill ranges of Jalgaon district, Maharashtra, India
}

\section{Laxminarayan Sonawane $^{1 *}$, Prasad Sonawane ${ }^{1}$ and Mayuresh Kulkarni ${ }^{2}$}

\author{
${ }^{1}$ Vanyajeev Sanrakshan Sanstha, Shiv Colony, Jalgaon-425001, Maharashtra, India \\ ${ }^{2}$ Institute of Natural History, Education and Research, Pune-411038, Maharashtra, India
}

*Corresponding Author: rahulsonawane1727@gmail.com

[Accepted: 30 November 2020]

[Cite as: Sonawane L, Sonawane P \& Kulkarni M (2020) New distributional record of Zingiber roseum (Roxb.) Roscoe from Satpuda hill ranges of Jalgaon district, Maharashtra, India. Tropical Plant Research 7(3): 619-621]

\section{INTRODUCTION}

Genus Zingiber Mill. (Zingiberaceae) is represented by 141 species distributed mainly in tropical forests of Asia. From Maharashtra 7 species have been reported (Sharma et al. 1996, Almeida 2009, Chandore et al. 2012). These plants are characterized by inflorescence arising directly from the rhizome with peduncle very short or absent. Earlier floristic studies in Satpuda hills of Khandesh region have not recorded any wild ginger species belonging to the genus Zingiber (Patil 2003, Kshirsagar 2008, Khan 2019). During our botanical survey of Satpuda hills, we came across a colony of herbaceous plants with distichous leaves with basal sheaths overlapping to form pseudostem, in Aamba Pani forest of Satpuda hills of Jalgaon district, on hill slopes dominated by Bamboo Dendrocalamus strictus (Roxb.) Nees and Karvi Strobilanthes callosa Nees vegetation, sharing habitat with Cheilocostus speciosus (J. Koenig) C. Specht, and Habenaria plantaginea Lindl. Detailed morphological examination of the specimen observed with the help of literature confirmed it as Zingiber roseum (Roxb.) Roscoe. Close examination with the help of pertinent literature revealed that this species is not recorded earlier from Satpuda hill ranges of Jalgaon district, and Khandesh region of Maharashtra. It is the new distributional record of this species from Satpuda ranges, Maharashtra state. The occurrence of this rare wild ginger species underlines its range extension from western ghats to Satpuda hills, signifying floral wealth of Satpuda hill ranges.

\section{MATERIALS AND METHODS}

During our botanical explorations in Satpuda hill ranges of Jalgaon district, we came across a tall perennial herb with inflorescence almost buried in the soil on a moist hill slope near rocky stream in the dense and shady forest patch. The plant specimen was collected for proper morphological investigation. The voucher specimen has been deposited in the herbarium collection of School of Environment \& Nature Conservation, Jalgaon. Thorough morphological scrutiny of the specimen was carried out and the taxa was confirmed by Dr. Milind Sardesai, Pune and Dr. R. G. Khose, Ahmednagar. It was identified as Zingiber roseum (Roxb.) Roscoe, a perennial herb.

\section{RESULTS}

Zingiber roseum (Roxb.) Roscoe, Trans. Linn. Soc. London 8:348. 1807; Baker in Hook. f., Fl. Bit. India 6: 244. 1892; M. Sabu, Zingiberaceae and Costaceae of South India, 244. 2006; Chandore et al. 2012. [Fig. 1]

Zingiber roseum an add. Fl. Maha., Kar. and Goa (Ind.) JBNHS, 109(3), Sep-Dec 2012.

Amomum roseum Roxb., Pl. Coast Coromandel 2: 15 pl. 126. 1800.

Vernacular name: Rosy Ginger.

Tall herbs. Rhizome thick, fleshy, pinkish from outside and white to pale yellow within. Roots many, fleshy. Pseudostem (leafy shoot) $c a$. $1.5 \mathrm{~m}$ tall, basal portion covered by long sheaths. Leaves short petiolate, ligulate, ligule bilobed, $c a .2 \mathrm{~cm}$, membranous; lamina 30-41 $\times 8-10 \mathrm{~cm}$, elliptic-lanceolate, leaf apex acuminate, base narrowed, cuneate, adaxially glabrous, abaxially white pubescent. Inflorescence produced directly from the rhizome, almost buried in the soil, peduncle very short, spike $4-6 \mathrm{~cm}$, dense. Bracts $3.5-5.0 \times 1.0 \mathrm{~cm}$, broadly 
ovate, imbricating, red. Flower $3 \mathrm{~cm}$ long, pale yellow. Calyx tubular, membranous. Corolla tube longer than bracts, white; segments subequal, red, dorsal lobe recurved, lateral lobes smaller, linear. Labellum shorter than the corolla lobes, oblong, cuneate, slightly three-lobed, margin recurved, somewhat crisp, white, with yellow markings on side lobes. Anther sessile; thecae $1 \mathrm{~cm}$ long; crest $0.7 \mathrm{~cm}$ long, red; style long filiform, stigma ciliate, slightly projecting from the anther crest. Capsule elliptic red, trigonous, seeds black, 6-7 $\times 3-4 \mathrm{~mm}$, aril white.

Flowering and fruiting: August-October.

Elevation: $800 \mathrm{~m}$.

Specimen examined: Munjoba-Aamba Pani forest, Yawal, Jalgaon district, Maharashtra, LMS-0015 (SoENC).

Distribution: Rare perennial herb. Prefers evergreen and moist deciduous forests at high altitude, growing on shady hill slopes near streams. In Satpuda hills a small colony of this species was found in moist shady slope near a rocky stream, dominated by Bamboo and Karvi vegetation. In Maharashtra it is earlier reported from Amboli (Sindhudurg district).


Figure 1. Zingiber roseum (Roxb.) Roscoe: A, Habit; B, Rhizome; C, Section of rhizome showing pale yellow middle portion; D, Flowers (Side view); E, Single flower; F, Flower (Top view); G, Flower showing ciliate stigma, slightly projecting from the anther crest; $\mathbf{H}$, Capsule and seeds with white aril.

\section{CONCLUSION}

Through perusal of literature and consultation with BSI herbarium, Pune, it was observed that Zingiber roseum (Roxb.) Roscoe is only reported from Amboli, Sindhudurg district in Maharashtra and is not earlier reported from Jalgaon, Dhule and Nandurbar districts of Maharashtra state (Sharma 1996, Patil 2003, Kshirsagar 2008, Almeida 2009, Chandore 2012, Khan 2019). Thus, this species has been recorded for the first time from Jalgaon district and Khandesh region of Maharashtra State. This clearly reveals, this species is rare to the flora of Maharashtra and even to the flora of India. This also shows that present paper is the second report of this species from Maharashtra. It is a new distributional record of this species from Satpuda hill ranges of Maharashtra. Encroachment, uncontrolled collection for trade, cattle grazing and man-made forest fires are serious threats to this already endangered species. There is urgent need to conserve and protect habitat of this rare perennial herb.

\section{ACKNOWLEDGEMENTS}

The authors express their gratitude towards Dr. Milind Sardesai (Savitribai Phule Pune University, Pune) Dr. R. G. Khose, (Professor of Botany), Ahmednagar for their kind help in confirming the taxa and Dr. Sudhakar Kurhade (Professor of Zoology), Ahmednagar, for his kind help in accessing the literature. They are also thankful to the authorities of Forest Department, for consistent support. Special thanks have been expressed for Gaurav Shinde, Bhushan Chaudhari, Ravindra Phalak, Balkrishna Devre, Ravindra Sonawane, Aman Gujar, Nitin Joshi for participation in field visits. 


\section{REFERENCES}

Almeida MR (2009) Flora of Maharashtra. Orient Press Mumbai, 5(A): 93-109.

Chandore AN, Malpure NV \& Yadav SR (2012) Zingiber roseum (Roxb.) Roscoe- an addition to the flora of Maharashtra, Karnataka and Goa (India). Journal of Bombay Natural History Society 109(3): 225.

Khan T (2019) Wild Flowers of Jalgaon District, A succinct field guide. Prashant Publication, Jalgaon, pp. 7779.

Kshirsagar SR \& Patil DA (2008) Flora of Jalgaon District, Maharashtra. Bishen Singh Mahendra Pal Singh, Dehradun, India, pp. 303-304.

Patil DA (2003) Flora of Dhule and Nandurbar District (Maharashtra). Bishan Singh Mahendra Pal Singh, Dehradun, pp. 570-573.

Sharma BD, Karthikeyan S \& Singh NP (1996) Flora of Maharashtra State (Monocotyledons). In: Flora of India, Series 2. Botanical Survey of India, Kolkata, pp. 65-87. 